Int. J. Morphol.,

35(2):733-739, 2017

\title{
Angiogenesis and Tumor Progression Inhibition of Cyclooxygenase-2 Selective Inhibitor Celecoxib Associated with Poly (lactic-co-glycolic acid) in Tumor Cell Line Resistant to Chemotherapy
}

Inhibición de Angiogénesis y Progresión Tumoral por Inhibidor Selectivo de Ciclooxigenasa-2 Celecoxib Asociado con Ácido (poli láctico co-glicólico) en Línea de Células Tumorales Resistentes a Quimioterapia

\author{
Ignacio Roa ${ }^{1.2,3}$; Mario Cantín ${ }^{4}$; Cristian Vilos ${ }^{5}$ - Carlos Rosas $^{6}$ \& David Lemus ${ }^{7}$
}

ROA, I.; CANTÍN, M.; VILOS, C.; ROSAS, C. \& LEMUS, D. Angiogenesis and tumor progression inhibition of cyclooxygenase-2 selective inhibitor celecoxib associated with poly (lactic-co-glycolic acid) in tumor cell line resistant to chemotherapy. Int. J. Morphol., 35(2):733-739, 2017.

SUMMARY: Although, antineoplastic therapies have now been developed reduction of tumor progression, it is necessary to find new therapeutic alternatives to suppress angiogenesis. Thus celecoxib $(\mathrm{Cx})$ has been used for its antiangiogenic action in combination with certain polymeric compounds such as poly (lactic co-glycolic acid) (PLGA) acid, which help to improve the bioavailability and avoid effects of long drug administrations. For this purpose we used a murine tumor model induced by mammary adenocarcinoma cells resistant to chemotherapy (TA3-MTXR). CX/PLGA inhibits the microvascular density, VEGF expression and cell proliferation in addition to increased apoptosis $(\mathrm{P}<0.0001)$. Cx reduces tumor progression in a concentration of $1000 \mathrm{ppm}$ associated with PLGA, reducing cell proliferation, the presence of VEGF and promoting apoptosis of multiresistant TA3 tumor cells.

KEY WORDS: Angiogenesis; Cancer; Celecoxib; PLGA; Apoptosis; VEGF; Cell Proliferation.

\section{INTRODUCCIÓN}

The growth of solid tumors and the subsequent formation of metastasis depend on multiple strategies presented by tumor cells like as the ability to proliferate; to evade apoptosis, and to be able to generate new blood vessels, allowing them to perpetuate in time and have the invasiveness (Hanahan \& Weinberg, 2011).

The enzyme cyclooxygenase-2 (COX-2), linked to prostaglandins synthesis from arachidonic acid, it would be responsible at least in part for the increase in tumor growth in addition to their accelerated proliferation. These conditions are overexpressed in a variety of epithelial cancers (Ninomiya et al., 2012; Pérez-Ruiz et al., 2012); also it has been observed that its overexpression is associated with poor prognosis, as well as an increase in proliferation, angiogenesis and tumor (Harizi et al., 2002) invasion. On the other hand; many studies have shown that selective COX2 inhibitors, could reduce these events (Husain et al., 2002; Hilmi \& Goh, 2006).

Celecoxib ( $\mathrm{Cx})$, selective COX-2 inhibitor; is currently used as anti-inflammatory agent for the treatment of rheumatoid arthritis and osteoarthritis, likewise is under investigation for the treatment of various malignant tumors and premalignant, including colorectal, breast, lung and prostate cancer (Ghosh et al., 2010).

\footnotetext{
${ }^{1}$ Unit of Morphology, Department of Basic Biomedical Sciences, Faculty of Health Sciences, Universidad de Talca, Chile.

${ }^{2}$ Doctoral Program in Morphology, Faculty of Medicine, Universidad de La Frontera, Temuco, Chile.

${ }^{3}$ Student Grant CONICYT-PCHA/Doctorado Nacional/2015-21150235.

${ }^{4}$ CEMyQ, Faculty of Medicine, Universidad de La Frontera, Temuco, Chile.

${ }^{5}$ Andres Bello University, School of Medicine, Center for Integrative Medicine and Innovative Science (CIMIS), Chile.

${ }^{6}$ Morphological Sciences Department, Faculty of Science, Universidad San Sebastian, Santiago, Chile.

${ }^{7}$ Experimental Embryology Laboratory of Molecular and Program of Anatomy and Developmental Biology, Institute of Biomedical Sciences, Faculty of Medicine, Universidad de Chile, Chile.
} 
ROA, I.; CANTÍN, M.; VILOS, C.; ROSAS, C. \& LEMUS, D. Angiogenesis and tumor progression inhibition of cyclooxygenase-2 selective inhibitor celecoxib associated with poly (lactic-co-glycolic acid) in tumor cell line resistant to chemotherapy. Int. J. Morphol., 35(2):733-739, 2017.

While the effects of $\mathrm{Cx}$ are favorable, oral administration for a long time, induces systemic, gastric and cardiovascular complications (Bombardier et al., 2000; Silverstein et al., 2000; Caldwell et al., 2006). Other studies indicate that frequent administration of high doses of oral $\mathrm{Cx}$ in experimental animals, cause mononuclear infiltration, hyperplasia and degeneration in the kidney, in addition to loss of some liver functions (Koçkaya et al., 2010).

With this background, it has been developed new strategies with decreased side effects for patients, such as the association to copolymers of lactic acid and glycolic acid (Vilos \& Velasquez, 2012). Poly lactic co-glycolic acid (PLGA) has been associated with multiple antiangiogenic agents in cancer therapies (Qi et al., 2011), such as the Cx (Dhanda \& Kompella, 2005; Amrite et al., 2006), achieving effects mainly in decreased angiogenesis as well as decreased expression of vascular endothelial growth factor (VEGF).

For this reason, we believe that $\mathrm{Cx}$ microencapsulated in PLGA reduces angiogenesis and tumor growth in a mammalian cell line tumor resistant to chemotherapy such as TA3-MTXR. Previously, we have shown that 1000 ppm Cx reduces liver metastases and promotes apoptosis and decreased angiogenesis and in mice with adenocarcinoma TA3 multiresistant (Rosas et al., 2013; 2014). Furthermore, Cx associated to PLGA, reduces angiogenesis in an in vivo model (Amrite et al.). In this research, we evaluated angiogenic and antitumor effects of Cx microencapsulated in PLGA in the development of a tumor in a murine model of mammary adenocarcinoma tumor cells resistant to chemotherapy.

\section{MATERIAL AND METHOD}

\section{Animal welfare}

Eight week old adult (20-25 g) female A/J strain mice $(\mathrm{n}=18)$ (Mus musculus) were obtained from our Central Animal Facility Central Vivarium. Experimental protocols were approved by the Bioethics Committee, Faculty of Medicine, Universidad de Chile (CBA FMUCH \#0498).

\section{Tumor growth assay}

The effect of 1000 ppm of Cx on in vivo growth of the TA3-MTXR murine mammary tumor cell line was assessed as described previously (Guerrero et al., 1992). Briefly, TA3MTXR cells come from a mammary murine carcinoma tumor cell line of ascitic growth. Methotrexate (MTX) resistance was performed by weekly passages of ascitic fluid from mice combined with increasing concentrations of MTX (0.1 to
$2.5 \mathrm{mg} / \mathrm{kg} / 48 \mathrm{~h}$ ) until the appropriate resistance. Twelve mice were inoculated in the right lower limb area, at day 0 with $2 \times 10^{6}$ cells $x$ mL tumor cells. At day 4 , mice were treated: $1000 \mathrm{ppm}$ of $\mathrm{Cx}(\mathrm{n}=6)$ intramuscular; $50 \mathrm{mg}$ of Cx / PLGA in a concentration of $1000 \mathrm{ppm}$ in sterile vehicle intramuscular $(n=6)$ and control $(n=6)$. Width and length of the tumor was measured with a digital caliper. The volume was then calculated as previously described (O'Reilly et al., 1997). Tumor growth was assessed until $19^{\text {th }}$ day where mice were euthanized for obtaining tumor and organs samples for histological procedures. For bioethical rules the experiment need to be stopped at $19^{\text {th }}$ day.

The experiments were validated by using the Wilcoxon Signed Rank test (Graph Pad Prism 5). P values $<0.05$ were considered as statistically significant.

\section{Drug preparation}

Cx 200 mg (Celebra ${ }^{\circledR}$ Pfizer $\left.^{\circledR}\right)$ was diluted in destiled water at 1000 ppm concentration, as described previously by Ragel et al. (2007). Cx / PLGA was encapsulated Celecoxib $200 \mathrm{mg}\left(\right.$ Celebra $^{\circledR}$ Pfizer $^{\circledR}$ ) in PLGA microcapsules according to described by Ayalasomayajula \& Kompella (2005), in which an average concentration of 1000 ppm was obtained. microparticles of between 0.5 and $10 \mu \mathrm{m}$ in diameter were obtained. Microencapsulation of the drug was conducted at the Center for the Development of Nanoscience and Nanotechnology, Universidad de Santiago, Chile.

\section{Immunohistochemistry}

Tumor was obtained at $19^{\text {th }}$ day and then fixed in a $10 \%$ buffered formalin solution for 48 hours. Serial sections of $5 \mathrm{~mm}$ were obtained. In order to evaluate cell proliferation, a Rabbit Polyclonal Anti - Human Ki-67 antibody (1:500) (Novocastra, Newcastle Upon Tyne, UK) was used. Briefly, $\mathrm{Ki}-67$ is a nuclear antigen associated to cel- lular proliferation. The polyclonal antibody (Novocastra, Cat\#NCL-Ki67-P) binds to Ki-67 antigen in the granular components of the nucleolus during late G1, S, G2 and M phases (Garrido et al., 2010). To detect Vascular Endothelial Growth Factor (VEGF), an Anti-VEGF165 Polyclonal Antibody (1:100) (Millipore, CA, USA) was used and then revealed by the "HistoMouse-MAX Kit" (Invitrogen, Camarillo, USA) which is based on the use of a secondary antibody conjugated with horseradish peroxidase and subsequently revealed with 3,3'-diaminobenzidine. Relative Expression was assessed with 30 microscopic fields and analyzed by Image J Software (NIH, USA). The average standard error was then calculated and applied to the tstudent test. 


\section{Evaluation of apoptosis}

To evaluate DNA fragmentation (an indicator of apop- tosis), the FragELTM DNA Fragmentation Detection Kit (Calbiochem, Darmstadt, Germany) was used. This system is based on labeling fragments of DNA of apop- totic cells by using a TUNEL assay. Histological sections of tumor and lung metastasis obtained at $19^{\text {th }}$ day were assessed and apoptotic nuclei were counted in light microscope.

\section{Microvascular density quantification}

To count of blood vessels were counted at 400x in histological sections from tumors and lungs obtained at $19^{\text {th }}$ day and were stained with Arteta, as described previously (Garrido et al.).
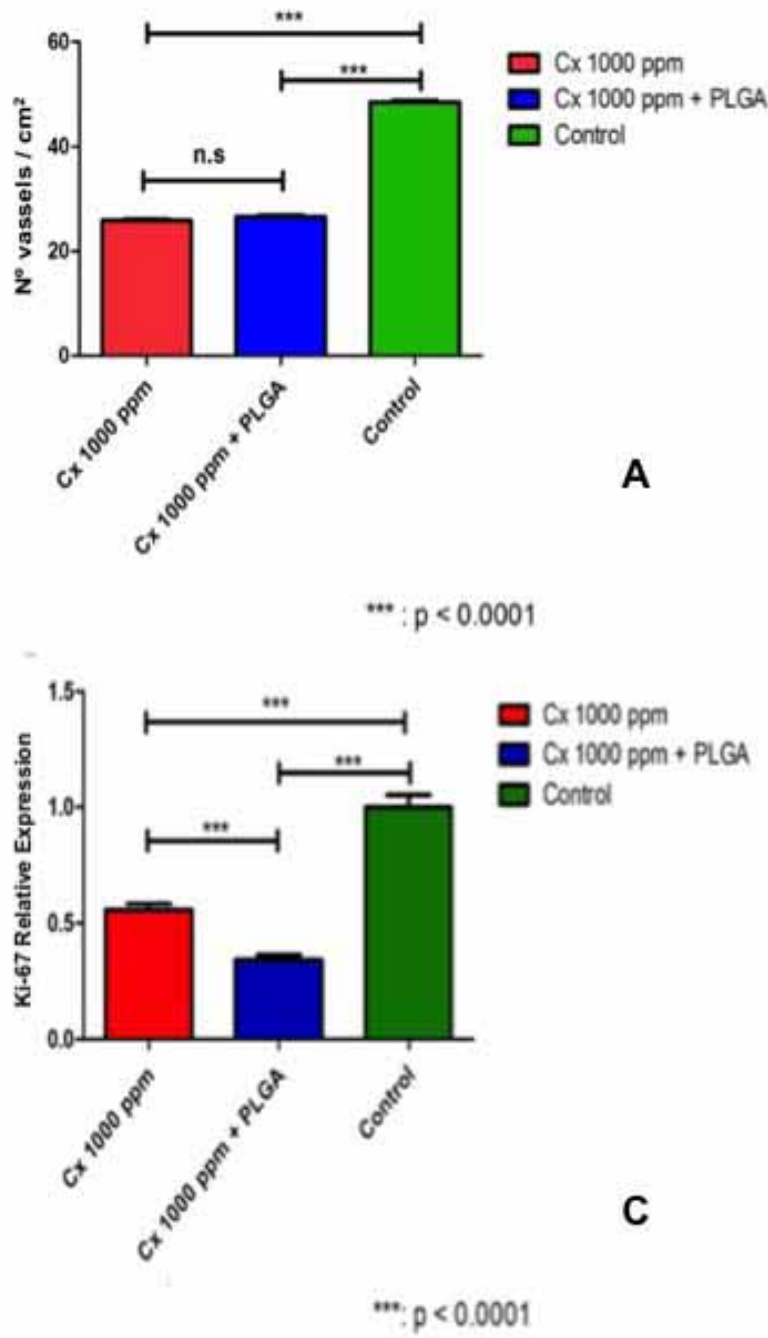

\section{RESULTS}

Cx decreases microvascular density in TA3-MTX-R tumor. In group 1 , treated with $\mathrm{Cx}$, the count in the tumor area, yielded an average of $26.55 \pm 0.32$ vessels $/ \mathrm{cm}^{2}$. By studying the group inoculated Cx / PLGA, an average of $25.8 \pm 0.26$ vessels $/ \mathrm{cm}^{2}$ was obtained. With respect to the group inoculated with the tumor TA3-MTX-R, an average of $48.5 \pm 0.28$ vessels $/ \mathrm{cm}^{2}$ (Fig.1A) it was obtained. When comparing the results of group 1,2 and 3 statistically significant differences ( $\mathrm{P}<0.0001$ ) they were obtained by comparing group 3 treated with $\mathrm{Cx}$ observing a marked decrease in vascular density in the tumor of mice treated with $\mathrm{Cx}$; but there is no significant decrease when comparing both presentations of the drug (Fig.2A, B, C).
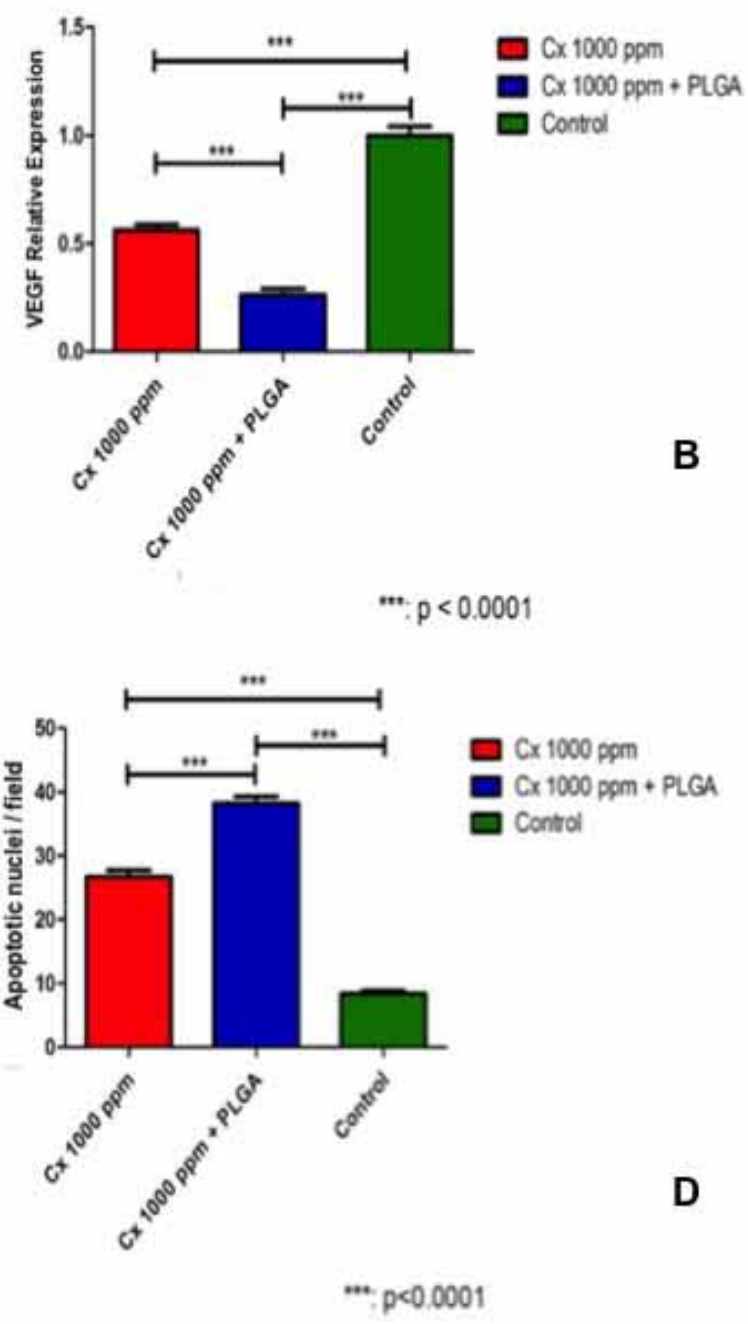

Fig. 1. Murine A/J mammary tumor (TA3 MTXR), microvascular density, VEGF, Ki-67 relative expression and apoptotic nuclei per field by study group. $\mathrm{p}<0.0001$. 
Celecoxib / PLGA decreases VEGF expression in TA3MTX-R tumor. With respect to the results found with VEGF expression in tumor areas observed, it was possible to observe cytoplasmic labeling pattern, which predominated in tumor cells. Group 2 had a lower immunostaining compared with Groups 1 and 3 (Fig. 2D, E, F), results were statistically significant ( $p<0.0001)$ (Fig.1B).

Celecoxib / PLGA decreases Ki67 expression in tumor TA3-MTX-R. The cuts of groups 1, 2 and 3 showed immunostaining KI-67, which indicates that there cell proliferation in all tumor level. Group 2 presented different areas with frank tumor cells in cell proliferation activity, with a characteristic pattern of nuclear staining, these cells morphologically correspond entirely to tumor cells (Fig. 2G, $\mathrm{H}, \mathrm{I})$. The results indicate that cell proliferation Group 2, was lower compared to that found in Group 1 and 3 , a difference that was statistically significant $(p<0.0001)$. Having $75 \%$ reduction of approx. the immunostaining if compared with Group 3 (Fig.1C).

Celecoxib / PLGA increases apoptosis in tumor TA3MTX-R. Immunohistochemical analysis of apoptosis at the level of cuts showed the presence of tumor nuclei and apoptotic bodies at different levels (Fig. 2J, K, L). The amount of apoptotic / field presented in Group $126.72 \pm$ cores was 1.003, with respect to the findings in Group 2 was $38.25 \pm 1.127$ finally was $0.5 \pm 8.36$ in the group 3 results were statistically significant ( $\mathrm{p}<0.0001)$ (Fig. 1D).

\section{DISCUSSION}

We propose that Cx / PLGA decreases tumor progression in a line of chemotherapy - resistant breast tumor. Furthermore, Cx / PLGA promotes apoptosis and decreased angiogenesis in the same tumor line.
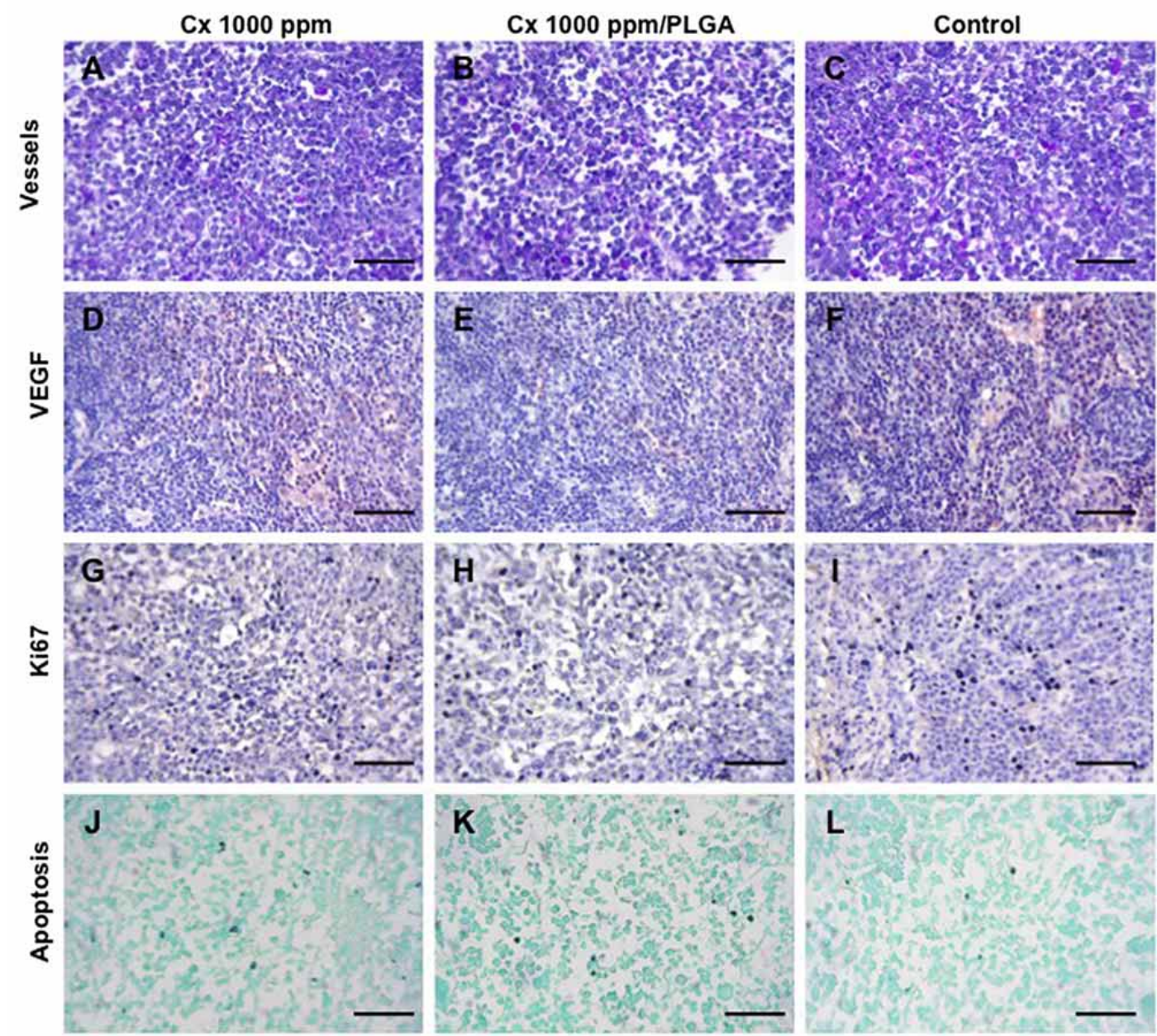

Fig. 2. Histological appearance of mouse (Mus musculus) TA3-MTX-R tumor: Tumoral microvessels stained with Arteta (A, B, C); VEGF expression (D, E, F); Ki-67 immunostaining (G, H, I); apoptotic nuclei with a TUNEL assay (J, K, L), by study group (400x; bar $100 \mu \mathrm{m})$. 
ROA, I.; CANTÍN, M.; VILOS, C.; ROSAS, C. \& LEMUS, D. Angiogenesis and tumor progression inhibition of cyclooxygenase-2 selective inhibitor celecoxib associated with poly (lactic-co-glycolic acid) in tumor cell line resistant to chemotherapy. Int. J. Morphol., 35(2):733-739, 2017.

Among the strategies employed by tumor cells in order to perpetuate in time include evasion of apoptosis, uncontrolled cell proliferation and angiogenesis (Hanahan \& Weinberg), the latter induced bynumerous pro-angiogenic factors, one of them is the VEGF (Gavalas et al., 2013). Considering this background, some drugs like $\mathrm{Cx}$ has been used in order to reduce these strategies (Dai et al., 2012).

Our results suggest that $\mathrm{Cx} / \mathrm{PLGA}$ reduces angiogenesis and proliferation and promotes apoptosis in TA3MTXR tumor cells compared to only $\mathrm{Cx}$ at a concentration of $1000 \mathrm{ppm}$, similar to those reported by Dai et al. results, where there was carcinogenesis inhibition and cancer development in rats in a similar concentration. Moreover, Rosas et al. (2014) showed that $\mathrm{Cx}$ suppresses angiogenesis in concentrations of $500 \mathrm{ppm}$ and $1000 \mathrm{ppm}$. Doses above $2000 \mathrm{ppm}$ induce tissue destruction (Rosas et al., 2014).

Cx / PLGA inhibit microvessel density in breast tumor in mice $A / J$, when this was compared with control and $\mathrm{Cx}$-only group. It should be noted that there was no statistical significance between the Cx / PLGA and CX-only groups. The decreased microvascular density effect is explained by the strong action of COX-2 and prostaglandins on the development of angiogenesis (Yao et al., 2011), wherein the selective inhibitors including $\mathrm{Cx}$, exhibit potent angiogenic inhibitory action.

Our immunohistochemical study showed that $\mathrm{Cx} /$ PLGA decreased Ki-67 and VEGF expression and increased of presence of apoptosis in TA3-MTXR tumor cells. Effects could be explained according to the previous results. It has been shown that COX-2 is overexpressed frequently in many gastrointestinal tract cancers, such as colorectal cancer, esophageal carcinoma, gastric cancer and pancreatic cancer (Ghosh et al.). Moreover, prostaglandin E2 (PGE2), the main effector of COX-2 is associated with apoptosis inhibition, tumor growth and angiogenesis. Its overexpression is actively involved in the development of angiogenesis and inhibition of apoptosis (Wang \& Dubois, 2010).

Brandão et al. (2013) reported a reduction in Ki-67 positive cells in patients with breast cancer treated with $\mathrm{Cx}$. In our study, Cx / PLGA 1000 ppm decreased proliferation of murine mammary tumor resistant to chemotherapy using the same lead. The association between COX-2 activity and proliferation has been proposed previously. Wu et al. (2003) demonstrated that $\mathrm{Cx}$ inhibits proliferation and induces apoptosis through the way of PGE2.

It has been proposed that pro-apoptotic effect of $\mathrm{Cx}$ is not only mediated by inhibition of $\mathrm{COX}-2$, but $\mathrm{Cx}$ affect the apoptotic signaling in multiple levels, such as decreased levels of expression of Mcl-1 and Survivin (Jendrossek, 2013). Our results demonstrated that Cx / PLGA promotes apoptosis in a murine mammary tumor. Other authors describe that binding of PGs to its receptor promotes evasion of apoptosis by increasing Survivin and Bcl-2 (Konturek et al., 2006) or through inhibition of VEGF signaling pathway / VEGFR-2 / Raf-1 / MAPK / ERK (Xu et al., 2012).

Regarding VEGF, it is the most critical factor associated to vasculogenesis, angiogenesis and lymphangiogenesis being VEGF-A an essential regulator of angiogenesis, acting primarily promoting cell division and migration in endothelial cells (Oklu et al., 2010). Previous studies show that $\mathrm{Cx}$ reduces serum levels of VEGF and COX2 (Han et al., 2014). Our results showed that Cx / PLGA reduces VEGF production from a murine mammary tumor. Furthermore, $\mathrm{Cx}$ could induce VEGF expression via hypoxia - inducible factor 1alpha (HIF-1a), and cell proliferation and migration through MAPK. These mechanisms explain at least in part, the association between VEGF and COX-2 / PG. The notion that VEGF is reduced using Cx is supported by Vaish \& Sanyal (2012) which defines a b-catenin relationship with COX-2 and Survivin.

In order to improve the bioavailability of drugs, it has been associated with PLGA, formulations and nano microparticles. These have been used in conjunction with multiple anti-angiogenic agents in antitumor therapy. Qi et al. used PNAS-4 human (Hpnas-4), a pro-apoptotic gene, which has the ability to inhibit tumor growth when overexpressed in tumor cells, and cisplatin in ovarian carcinoma, which brought about an increase in the induction of apoptosis, inhibition of cell proliferation and suppression of angiogenesis.

Moreover Zhang et al. (2010) studied the effects of temozolomide, drug employed in anticancer therapy in CNS tumors, microencapsulated in PLGA, together with Vetalanib inhibitor of the VEGF receptor on a orthotopic glioma model in rats, these found that combination of these drugs resulted in a decrease in tumor volume, thus improving the survival time and an increase in the number of apoptotic tumor cells and inhibition of tumor angiogenesis. Chen et al. (2012) used Docetaxel, a potent antitumor agent, used as chemotherapeutic, which was microencapsulated with PLGA, and used in the human hepatoma, where it was shown to be effective at reducing tumor angiogenic activity. Other substances have been encapsulated with PLGA in anticancer therapy. Mukerjee \& Vishwanatha (2009) used curcumin loaded PLGA nanospheres, as a therapy against prostate cancer. These authors concluded that curcumin associating with PLGA nanospheres was delivered over a longer sustained time period, thus becoming a potential candidate for therapy in cell lines of prostate cancer. 
Within the drugs used in antiangiogenic therapy is $C x$ which has been occupied for assessing decreased angiogenesis in ocular vascular pathologies, which has seen a decrease in vascularity (Amrite et al.). Similar results to those seen by Dhanda \& Kompella, which have reported that the use of $\mathrm{Cx}$ microencapsulated in PLGA significantly decreased VEGF levels, when administered at the level of the trachea, a model of pulmonary tumor. These results would indicate that the presence of the particles help improve drug levels in tumor level, allowing this to be released for longer, improving local response. Other studies indicate a reduction in liver metastasis (Roa $e t$ al., 2015) and lung, as well as the microvasculature (Roa et al., 2016) was used when Cx / PLGA in strain AJ versus Cx.

Multiple drugs among them $\mathrm{Cx}$ associated with PLGA or other type of polymer are feasible route of administration as they may reduce the frequency of administration, leading to greater tolerance by the patient; and an increased benefit due to the elimination of fluctuations in serum drug levels (Rafiei \& Haddadi, 2017). The potential decrease in the total dose required for treatment, due to greater efficiency in the utilization of the administered dose and the potential reduction of adverse effects as it decreases the magnitude of the amount of drug released into the body at the time application (Saez et al., 2007), as well as the decrease in recurrence of tumors, are its main advantages (Will et al., 2016). All this added to the PLGA safety when administered in different tissues such as salivary glands (Cantín et al., 2013), or muscle tissue, (Acuña et al., 2011), which makes it a favorable environment for such partnerships biomaterial.

\section{CONCLUSION}

$\mathrm{Cx}$ reduces tumor progression in a concentration of $1000 \mathrm{ppm}$ associated with PLGA, reducing cell proliferation, the presence of VEGF and promoting apoptosis of multiresistant TA3 tumor cells. Antiangiogenic and antitumor effects of $\mathrm{Cx}$ are correlated with their activity in other tumor cell lines, suggesting that prostaglandins (PGs) and VEGF production are involved. $\mathrm{Cx}$ associated to PLGA proves lowering drug tumor progression, and it is currently used in the treatment of some cancers, associated with other drugs.

ACKNOWLEDGMENTS: We thank to Irma Orellana for her technical support.

ROA, I.; CANTÍN, M.; VILOS, C.; ROSAS, C. \& LEMUS, D. Inhibición de angiogénesis y progresión tumoral por inhibidor selectivo de ciclooxigenasa-2 celecoxib asociado con ácido (poli láctico co-glicólico) en línea de células tumorales resistentes a quimioterapia. Int. J. Morphol., 35(2):733-739, 2017.
RESUMEN: Si bien actualmente se han desarrollado terapias antineoplásicas que permiten reducir de cierta manera el avance tumoral, es necesario buscar nuevas alternativas terapéuticas que permitan suprimir la angiogénesis. Es así como el Celecoxib (Cx) ha sido utilizado por su acción antiangiogénica en combinación con algunos compuestos poliméricos, tal como el ácido poli (láctico co-glicólico) (PLGA), el cual ayudaría a mejorar la biodisponibilidad y evitaría efectos derivados de largas administraciones del fármaco. Para tal efecto se ha utilizado un modelo tumoral murino, inducido por células tumorales de adenocarcinoma mamario resistente a la quimioterapia (TA3-MTXR). Los resultados indican que CX/PLGA inhibe la microvascularización, expresión de VEGF y la proliferación celular además del aumento de la apoptosis $(\mathrm{P}<0,0001)$. El efecto antitumoral del $\mathrm{Cx}$ está bien reportado en la literatura; este sumado a la microencapsulación con PLGA, aportarían un sistema de administración útil, ya que nos otorga una administración sostenida en el tiempo, los cual podría ayudar a mantener los niveles de droga durante un período más prolongado, lo cual sería beneficioso en la terapia tumoral.

PAlabraS ClaVE: Angiogenesis; Cáncer; Celecoxib; PLGA; Apoptosis; VEGF; Proliferación celular.

\section{REFERENCES}

Acuña, L.; Suazo, G. I.; Zavando, D.; Elgueta, S.; Velásquez, L.; Vilos, C. \& Cantín, M. Morphometric and histopathologic changes in skeletal muscle induced for injectable PLGA microparticles. Int. J. Morphol., 29(2):4038, 2011.

Amrite, A. C.; Ayalasomayajula, S. P.; Cheruvu, N. P. S. \& Kompella, U. B. Single periocular injection of celecoxib-PLGA microparticles inhibits diabetes-induced elevations in retinal PGE2, VEGF, and vascular leakage. Invest. Ophthalmol. Vis. Sci., 47(3):1149-60, 2006.

Ayalasomayajula, S. P. \& Kompella, U. B. Subconjunctivally administered celecoxib-PLGA microparticles sustain retinal drug levels and alleviate diabetes-induced oxidative stress in a rat model. Eur. J. Pharmacol., 511(23):191-8, 2005.

Brandão, R. D.; Veeck, J.; Van de Vijver, K. K.; Lindsey, P.; de Vries, B.; van Elssen, C. H.; Blok, M. J.; Keymeulen, K.; Ayoubi, T.; Smeets, H. J.; Tjan-Heijnen, V. C. \& Hupperets, P. S. A randomised controlled phase II trial of pre-operative celecoxib treatment reveals anti-tumour transcriptional response in primary breast cancer. Breast Cancer Res., 15(2):R29, 2013.

Bombardier, C.; Laine, L.; Reicin, A.; Shapiro, D.; Burgos-Vargas, R.; Davis, B.; Day, R.; Ferraz, M. B.; Hawkey, C. J.; Hochberg, M. C.; Kvien, T. K.; Schnitzer, T. J. \& VIGOR Study Group. Comparison of upper gastrointestinal toxicity of rofecoxib and naproxen in patients with rheumatoid arthritis. VIGOR Study Group. N. Engl. J. Med., 343(21):1520$8,2000$.

Caldwell, B.; Aldington, S.; Weatherall, M.; Shirtcliffe, P. \& Beasley, R. Risk of cardiovascular events and celecoxib: a systematic review and metaanalysis. J. R. Soc. Med., 99(3):132-40, 2006.

Chen, Z. K.; Cai, M. X.; Yang, J.; Lin, L. W.; Xue, E. S.; Huang, J.; Wei, H. F.; Zhang, X. J. \& Ke, L. M. Chemotherapy with PLGA microspheres containing docetaxel decreases angiogenesis in human hepatoma xenograft. Med. Oncol., 29(1):62-9, 2012.

Dai, Z. J.; Ma, X. B.; Kang, H. F.; Gao, J.; Min, W. L.; Guan, H. T.; Diao, Y.; Lu, W. F. \& Wang, X. J. Antitumor activity of the selective cyclooxygenase2 inhibitor, celecoxib, on breast cancer in vitro and in vivo. Cancer Cell Int., 12(1):53, 2012.

Dhanda, D. \& Kompella, U. Single intratracheal administration of CelecoxibPLGA microparticles reduces PGE2 and VEGF levels in a mouse model for lung tumors. A. A. P. S., 003016, 2005.

Garrido, O.; Letelier, R.; Rosas, C.; Fuenzalida, M.; Ferreira, A. \& Lemus, D. Betamethasone inhibits tumor development, microvessel density and 
prolongs survival in mice with a multiresistant adenocarcinoma TA3. Biol. Res., 43(3):317-22, 2010.

Gavalas, N. G.; Liontos, M.; Trachana, S. P.; Bagratuni, T.; Arapinis, C.; Liacos, C.; Dimopoulos, M. A. \& Bamias A. Angiogenesis-related pathways in the pathogenesis of ovarian cancer. Int. J. Mol. Sci., 14(8):15885-909, 2013.

Ghosh, N.; Chaki, R.; Mandal, V. \& Mandal, S. C. COX-2 as a target for cancer chemotherapy. Pharmacol. Rep., 62(2):233-44, 2010.

Guerrero, A.; Zipper, J. \& Dabancens, A. Actividad antineoplásica ejercida por Quinacrina oral sobre tumores malignos trasplantables en ratón. Rev. Chil. Cancerol. Hematol., 2:119-22, 1992.

Han, X.; Li, H.; Su, L.; Zhu, W.; Xu, W.; Li, K.; Zhao, Q.; Yang, H. \& Liu, H. Effect of celecoxib plus standard chemotherapy on serum levels of vascular endothelial growth factor and cyclooxygenase-2 in patients with gastric cancer. Biomed. Rep., 2(2):183-7, 2014.

Hanahan, D. \& Weinberg, R. A. Hallmarks of cancer: the next generation. Cell, 144(5):646-74, 2011

Harizi, H.; Juzan, M.; Pitard, V.; Moreau, J. F. \& Gualde, N. Cyclooxygenase2 -issued prostaglandin $\mathrm{e}(2)$ enhances the production of endogenous IL10, which down-regulates dendritic cell functions. J. Immunol., 168(5):2255-63, 2002.

Hilmi, I. \& Goh, K. L. Chemoprevention of colorectal cancer with nonsteroidal anti-inflammatory drugs. Chin. J. Dig. Dis., 7(1):1-6, 2006.

Husain, S. S.; Szabo, I. L. \& Tamawski, A. S. NSAID inhibition of GI cancer growth: clinical implications and molecular mechanisms of action. Am. J. Gastroenterol., 97(3):542-53, 2002.

Jendrossek, V. Targeting apoptosis pathways by Celecoxib in cancer. Cancer Lett., 332(2):313-24, 2013.

Koçkaya, E. A.; Selmanoglu, G.; Kismet, K. \& Akay, M. T. Pathological and biochemical effects of therapeutic and supratherapeutic doses of celecoxib in Wistar albino male rats. Drug Chem. Toxicol., 33(4):410-4, 2010.

Konturek, P. C.; Konturek, S. J. \& Brzozowski, T. Gastric cancer and Helicobacter pylori infection. J. Physiol. Pharmacol., 57 Suppl. 3:51-.65, 2006.

Cantín, M.; Miranda, P.; Suazo Galdames, I.; Zavando, D.; Arenas, P.; Velásquez, L. \& Vilos, C. In vivo biocompatibility of the PLGA microparticles in parotid gland. Int. J. Clin. Exp. Pathol., 6(11):24122418, 2013.

Mukerjee, A. \& Vishwanatha, J. K. Formulation, characterization and evaluation of curcumin-loaded PLGA nanospheres for cancer therapy. Anticancer. Res., 29(10):3867-75, 2009.

Ninomiya, I.; Nagai, N.; Oyama, K.; Hayashi, H.; Tajima, H.; Kitagawa, H.; Fushida, S.; Fujimura, T. \& Ohta, T. Antitumor and anti-metastatic effects of cyclooxygenase- 2 inhibition by celecoxib on human colorectal carcinoma xenografts in nude mouse rectum. Oncol. Rep., 28(3):777-84, 2012.

Oklu, R.; Walker, T. G.; Wicky, S. \& Hesketh, R. Angiogenesis and current antiangiogenic strategies for the treatment of cancer. J. Vasc. Interv. Radiol., 21(12):1791-805, 2010.

O'Reilly, M. S.; Boehm, T.; Shing, Y.; Fukai, N.; Vasios, G.; Lane, W. S.; Flynn, E.; Birkhead, J. R.; Olsen, B. R. \& Folkman, J. Endostatin: an endogenous inhibitor of angiogenesis and tumor growth. Cell, 88(2):27785, 1997.

Pérez-Ruiz, E.; Cazorla, O.; Redondo, M.; Pérez, L.; Álvarez, M.; Gallego, E.; Trigo, J. M.; Medina, J. A.; Matilla, A. \& Rueda, A. Immunohistochemical expression of cyclooxygenase- 2 in patients with advanced cancer of the larynx who have undergone induction chemotherapy with the intention of preserving phonation. Clin. Transl. Oncol., 14(9):682-8, 2012.

Qi, X.; Song, X.; Liu, P.; Yi, T.; Li, S.; Xie, C.; Zheng, Y.; Bai, Y.; Sun, C.; Wei, Y. \& Zhao, X. Antitumor effects of PLGA nanoparticles encapsulating the human PNAS-4 gene combined with cisplatin in ovarian cancer. Oncol. Rep., 26(3):703-10, 2011.

Rafiei, P. \& Haddadi, A. Docetaxel-loaded PLGA and PLGA-PEG nanoparticles for intravenous application: pharmacokinetics and biodistribution profile. Int. J. Nanomedicine, 12:935-47, 2017.

Ragel, B. T.; Jensen, R. L.; Gillespie, D. L.; Prescott, S. M. \& Couldwell, W.
T. Celecoxib inhibits meningioma tumor growth in a mouse xenograft model. Cancer, 109(3):588-97, 2007.

Roa, I.; Moraga, J.; Caníin, M.; Rosas, C. \& Lemus, D. Antimetastatic effect of Celecoxib/PLGA in a TA3-MTX-R murine breast adenocarcinoma model. Int. J. Morphol., 33(2):558-65, 2015.

Roa, I.; Cantín, M.; Muñoz, M.; Rosas, C. \& Lemus, D. Celecoxib/PLGA suppresses angiogenesis and lung metastasis of murine experimental breast cancer. Int. J. Morphol., 34(1):335-41, 2016.

Rosas, C. C.; Roa, I.; Sinning, O. M.; Fuenzalida, B. M. \& Lemus, A. D. Celecoxib effect in a multiresistant variant of the TA3 tumor. A histological description. Int. J. Morphol., 31(2):392-8, 2013.

Rosas, C.; Sinning, M.; Ferreira, A.; Fuenzalida, M. \& Lemus, D. Celecoxib decreases growth and angiogenesis and promotes apoptosis in a tumor cell line resistant to chemotherapy. Biol. Res., 47(1):27, 2014.

Saez, V.; Hernández, J. R. \& Peniche, C. Las microesferas como sistemas de liberación controlada de péptidos y proteínas. Biotecnol. Apl., 24(2):98107, 2007.

Silverstein, F. E.; Faich, G.; Goldstein, J. L.; Simon, L. S.; Pincus, T.; Whelton, A.; Makuch, R.; Eisen, G.; Agrawal, N. M.; Stenson, W. F.; Burr, A. M.; Zhao, W. W.; Kent, J. D.; Lefkowith, J. B.; Verburg, K. M. \& Geis, G. S. Gastrointestinal toxicity with celecoxib vs nonsteroidal anti-inflammatory drugs for osteoarthritis and rheumatoid arthritis: the CLASS study: A randomized controlled trial. Celecoxib Long-term Arthritis Safety Study. JAMA, 284(10):1247-55, 2000.

Vaish, V. \& Sanyal, S. N. Role of Sulindac and Celecoxib in the regulation of angiogenesis during the early neoplasm of colon: exploring PI3-K/PTEN/ Akt pathway to the canonical Wnt/b-catenin signaling. Biomed. Pharmacother, 66(5):354-67, 2012.

Vilos, C. \& Velasquez, L. A. Therapeutic strategies based on polymeric microparticles. J. Biomed. Biotechnol., 2012:672760, 2012.

Wang, D. \& Dubois, R. N. Eicosanoids and cancer. Nat. Rev. Cancer, 10(3):181-93, 2010.

Will, O. M.; Purcz, N.; Chalaris, A.; Heneweer, C.; Boretius, S.; Purcz, L.; Nikkola, L.; Ashammakhi, N.; Kalthoff, H.; Glüer, C. C.; Wiltfang, J.; Açil, Y. \& Tiwari, S. Increased survival rate by local release of diclofenac in a murine model of recurrent oral carcinoma. Int. J. Nanomedicine, 11:5311-21, 2016.

Wu, G. S.; Zou, S. Q.; Liu, Z. R.; Tang, Z. H. \& Wang, J. H. Celecoxib inhibits proliferation and induces apoptosis via prostaglandin E2 pathway in human cholangiocarcinoma cell lines. World J. Gastroenterol., 9(6):1302-6, 2003.

Xu, T.; Wang, N. S.; Fu, L. L.; Ye, C. Y.; Yu, S. Q. \& Mei, C. L. Celecoxib inhibits growth of human autosomal dominant polycystic kidney cystlining epithelial cells through the VEGF/Raf/MAPK/ERK signaling pathway. Mol. Biol. Rep., 39(7):7743-53, 2012.

Yao, L.; Liu, F.; Hong, L.; Sun, L.; Liang, S.; Wu, K. \& Fan, D. The function and mechanism of COX-2 in angiogenesis of gastric cancer cells. J. Exp. Clin. Cancer Res., 30:13, 2011.

Zhang, Y. H.; Yue, Z. J.; Zhang, H.; Tang, G. S.; Wang, Y. \& Liu, J. M. Temozolomide/PLGA microparticles plus vatalanib inhibits tumor growth and angiogenesis in an orthotopic glioma model. Eur. J. Pharm. Biopharm., 76(3):371-5, 2010.

\section{Dirección de Correspondencia: \\ Dr. Ignacio Roa Henríquez \\ Unidad de Morfología}

Departamento de Ciencias Básicas Biomédicas Facultad de

Ciencias de la Salud

Universidad de Talca Av. Lircay s/n Talca

CHILE

E-mail: iroa@utalca.cl

Recibido : 03-01-2017 Aceptado: 31-03-2017 